\title{
Spatial Variability in Soil Properties and Plant Nutrients of Paddy Rice in Mwea, Kenya
}

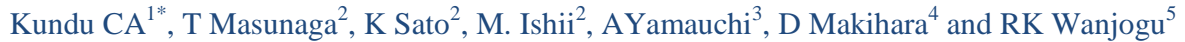

${ }^{1}$ Kenya Agricultural and Livestock Research Organization (KALRO), Box 169-50100, Kakamega, Kenya

${ }^{2}$ Faculty of Life and Environmental Sciences, Shimane University, 1060 Nishikawatsu-cho, Matsue city, Shimane 690-8504 Japan

${ }^{3}$ Graduate School of Bioagricultural Sciences, Nagoya University, Furo-cho, Chikusa-ku, Nagoya 464-8601, Japan

${ }^{4}$ International Co-operation Centre for Agricultural Education (ICCAE), Nagoya University, Furo-cho, Chikusa-ku, Nagoya 464-8601, Japan

${ }^{5}$ Mwea Irrigation Agricultural Development Centre (MIAD), Box 210-10303, Wang'uru, Kenya

\begin{abstract}
Article History
Received: 29.10 .2020

Accepted: 10.11 .2020

Published: 17.11 .2020
\end{abstract}

Journal homepage:

http://www.easpublisher.com/easjals/

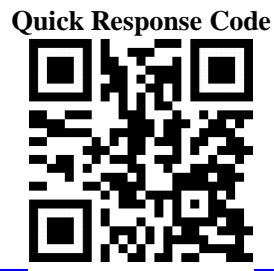

Abstract: Lowlands constitute major environment for rice cultivation in Kenya, but declining soil productivity has led to low poor quality yields. This study assessed soil and yield quality of rice in Mwea irrigation scheme. Surface $0-15 \mathrm{~cm}$ soil was sampled for laboratory analysis. Rice straw and grain was collected and analysed for total nutrient. Results obtained for soil and plant was evaluated basing on nutrient guidelines for rice. Results indicated that soil $\mathrm{pH}$ was moderately high and salt concentration negligible $(<0.4 \mathrm{dS} / \mathrm{m})$. Soil total carbon was moderately high while total nitrogen was low. Available phosphorus, sulphur and silica all exceeded deficiency level for rice. Exchangeable $\mathrm{Ca}^{2+}$ and $\mathrm{Mg}^{2+}$ dominated compared to exchangeable $\mathrm{K}^{+}$and $\mathrm{Na}^{+}$; and as a result severe $\mathrm{K}^{+}$deficiency because of cation imbalance existed. Among micronutrients, soil $\mathrm{Fe}, \mathrm{Mn}$ and $\mathrm{Cu}$ were high while $\mathrm{Zn}$ was deficient. Grain yields were below optimum and plant analyses revealed deficiencies in straw total sulphur, $\mathrm{K}$ and $\mathrm{Ca}$ in some units. Grain samples showed deficiency in total $\mathrm{Ca}, \mathrm{Fe}, \mathrm{K}, \mathrm{Mg}$ and $\mathrm{S}$. Soil condition and nutrient concentrations affected nutrient accumulation in straw and grain. Appropriate soil management practices should be considered for improved quality and quantity of yields.

Keywords: Cation imbalance, lowlands, Mwea irrigation scheme, soil nutrient.

Copyright () 2020 The Author(s): This is an open-access article distributed under the terms of the Creative Commons Attribution 4.0 International License (CC BY-NC 4.0) which permits unrestricted use, distribution, and reproduction in any medium for non-commercial use provided the original author and source are credited.

\section{INTRODUCTION}

Low productivity of food crops because of little or no nutrient application in Sub-Saharan Africa (SSA) contributes to food insecurity [1]. Although mineral fertilizers are widely used globally, their use remains low [2]. The fertilizer is not targeted to specific crop, soil and agro-ecological conditions and application rates are 'blanket' [3]. Importance of rice has increased in SSA [4]. In Kenya, demand exceeds production and the gap is filled through huge and costly imports. Current production meets $20 \%$ of total demand and consumption projected to rise with increasing population and changes in eating habits [5]. To attain self-sufficiency, total domestic production must increase at $9.3 \%$ per annum [6]. Stakeholders must understand impediments that exist along rice value chain and import process and explore opportunities to benefit all [7].

Plant growth and development is reliant on nutrient from soil and nutrients present in tissues are dependent on demand and soil availability [8]. Humans require nutrients obtained from daily diets.
Unfortunately, majority of plant derived food contains low bioavailable nutrients. Current high yielding white rice though a major staple food and energy source is poor in essential micronutrients such as $\mathrm{Zn}$ [9].

Variability in soil and yield exist which may lead to site-specific management [10]. Grain quality after yield is important for rice production and nutritional quality is considered as one of the main objectives for rice improvement [11].

In Kenya's rice production systems, fertilization is restricted to $\mathrm{N}$ and $\mathrm{P}$ [12] and relationship between soil minerals and grain quality has not received any attention. This work aimed at analyzing soil nutrient supplying power and its effect on nutrient accumulation in Kenya's irrigated rice system.

\section{MATERIALS AND METHODS}

Mwea irrigation scheme is located on lower slopes of Mt. Kenya in Central Kenya (Figure 1). Total area is $12,282 \mathrm{ha}$ with about 9,000ha under rice production. It is divided into five units; Mwea, Thiba, 
Wamumu, Karaba and Tebere located at different topographical elevation. The scheme gets water from two rivers; Nyamindi; serving Tebere and Thiba serving Mwea, Thiba, Wamumu and Karaba (Figure 1).

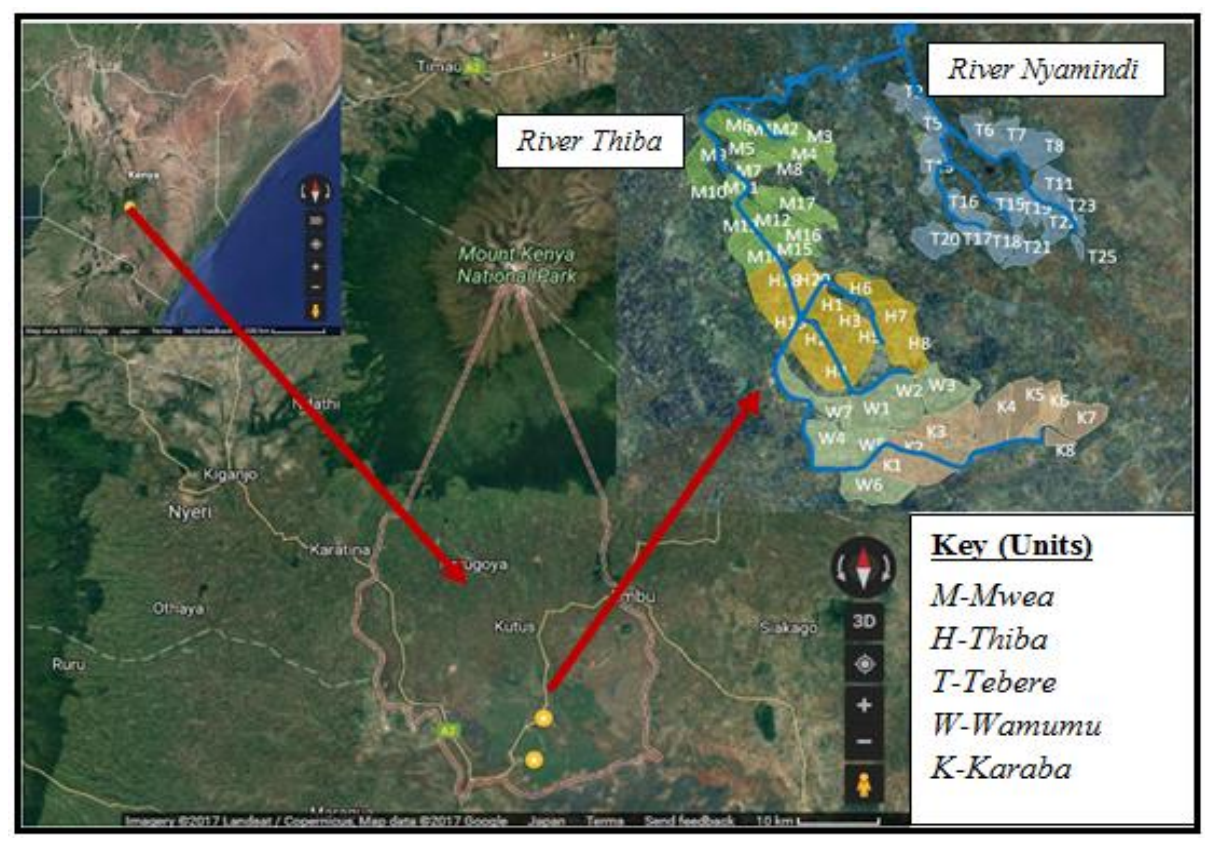

Fig-1: Location and layout of Mwea Irrigation Scheme

Surface $0-15 \mathrm{~cm}$ soil was collected from benchmarked farms and analysed for $\mathrm{pH}$, electrical conductivity (EC), total carbon (TC), total nitrogen (TN), available silica $\left(\mathrm{SiO}_{2}\right)$, available sulphur (S), available phosphorus $\left(\mathrm{P}_{2} \mathrm{O}_{5}\right)$, available micronutrients and exchangeable cations using standard procedures.

At harvesting, straw and grain samples were collected from the same fields and analysed for total elements. They were digested in $\mathrm{HNO}_{3}$ according to Koyama and Sutoh, [13] and concentrations determined by Inductively Coupled Plasma-Atomic Spectroscopy (ICPE-9000, Shimadzu).

\section{STATISTICAl AnAlysis}

Data were subjected to analysis of variance using $\mathrm{R}$ software version 3.4 .0 for windows and statistically significant differences between means compared at 5\% level using Duncan Multiple range test. Soil and plant nutrient concentrations were evaluated basing on guidelines for rice.

\section{Results AND DiscuSSIONS \\ Soil Properties} in Table 1.

Mean values for soil properties are presented

Table-1: Soil chemical properties

\begin{tabular}{|c|c|c|c|c|c|c|}
\hline \multirow[t]{2}{*}{ Parameter } & \multirow{2}{*}{$\begin{array}{c}\text { Deficiency } \\
\text { level* }\end{array}$} & \multicolumn{5}{|c|}{ Unit } \\
\hline & & Mwea & Thiba & Wamumu & Karaba & Tebere \\
\hline $\mathrm{pH}$ & & 6.2 & 6.2 & 6.9 & 6.9 & 7.0 \\
\hline $\mathrm{EC}(\mathrm{dS} / \mathrm{m})$ & $<4$ & 0.12 & 0.17 & 0.17 & 0.23 & 0.18 \\
\hline $\mathrm{TN}(\mathrm{g} / \mathrm{kg})$ & & 1.30 & 1.20 & 0.90 & 0.87 & 1.43 \\
\hline $\mathrm{TC}(\mathrm{g} / \mathrm{kg})$ & & 20.1 & 18.9 & 16.2 & 15.6 & 24.0 \\
\hline Avail. S(mg/kg) & 9 & 48.2 & 51.5 & 60.0 & 90.1 & 78.7 \\
\hline Avail. $\mathrm{P}_{2} \mathrm{O}_{5}(\mathrm{mg} / \mathrm{kg})$ & $12-20$ & 87.0 & 123 & 50.0 & 36.4 & 152 \\
\hline Avail. $\mathrm{SiO}_{2}(\mathrm{mg} / \mathrm{kg})$ & 86 & 425 & 429 & 507 & 498 & 608 \\
\hline \multicolumn{7}{|c|}{ Exchangeable cations $\left(\mathrm{cmol}_{\mathrm{c}} / \mathrm{kg}\right)$} \\
\hline $\mathrm{Ca}^{2+}$ & 1 & 33.0 & 41.7 & 47.2 & 51.7 & 36.9 \\
\hline $\mathrm{Mg}^{2+}$ & 1 & 20.6 & 21.7 & 24.4 & 35.4 & 21.2 \\
\hline $\mathrm{K}^{+}$ & 0.2 & 0.08 & 0.12 & 0.36 & 0.40 & 0.56 \\
\hline$(\mathrm{Ca}+\mathrm{Mg}) / \mathrm{K}$ ratio & 100 & 625 & 533 & 240 & 226 & 150 \\
\hline \multicolumn{7}{|c|}{ Available micronutrients $(\mathrm{mg} / \mathrm{kg})$} \\
\hline $\mathrm{Fe}$ & $4-5$ & 134.0 & 94.8 & 69.4 & 68.5 & 90.9 \\
\hline $\mathrm{Mn}$ & $3-30$ & 72.9 & 198.0 & 136.0 & 112.0 & 94.7 \\
\hline $\mathrm{Cu}$ & 0.1 & 2.10 & 1.14 & 4.77 & 5.64 & 2.90 \\
\hline $\mathrm{Zn}$ & 2 & 0.22 & 0.26 & 0.55 & 0.62 & 0.63 \\
\hline
\end{tabular}

*Dobermann and Fairhust, 2000 [14] 
Soil $\mathrm{pH}$ is a driver of soil fertility because it influences availability and uptake of nutrients and toxins [15]. Soil $\mathrm{pH}$ increased down the elevation from Mwea to Karaba (Table 1). This high soil $\mathrm{pH}$ is attributed to basaltic parent material and dry climate as reported in earlier studies [16]. Values of 5.5 to 7.0 are appropriate for provision of nutrients in grain and vegetable crops [15] therefore values observed are appropriate.

EC was low and increased down the elevation thus considered non-saline. Results revealed low TN and moderate TC that decreased down elevation (Table 1). N supply limits grain yield and demand for other macronutrients in rice [17]. Moderate soil TC observed could be due to stubble and low TN because of low rates and improper application methods that lead to $\mathrm{N}$ losses despite widespread use of $\mathrm{N}$ fertilizers. Effluents from rice fields indicated high nitrates $(>5 \mathrm{mg} / \mathrm{l})$ according to Onderi [18], an indication of $\mathrm{N}$ loss in irrigation water. A common practice of residue removal [16] exacerbates $\mathrm{N}$ loss.

Available $\mathrm{P}_{2} \mathrm{O}_{5}, \mathrm{~S}, \mathrm{SiO}_{2}, \mathrm{Fe}, \mathrm{Mn}$ and $\mathrm{Cu}$ exceeded deficiency level. High $\mathrm{S}$ concentration observed is attributed to widespread use of ammonium sulphate fertilizers [11]. Studies on clays by Muriithi et al., [19] indicated 42-50\% silica, thus high $\mathrm{SiO}_{2}$ content.

Exchangeable $\mathrm{Ca}^{2+}$ and $\mathrm{Mg}^{2+}$ dominated and exceeded deficiency level while $\mathrm{K}^{+}$was deficient in Mwea and Thiba (Table 1). Cations increased down the elevation due to accumulation in lower depression area.
Cation imbalance was evident and severe in Mwea and Thiba. $\mathrm{K}$ fertilizers are seldom used, and straw removal exacerbates $\mathrm{K}$ deficiency. Zn was below deficiency level because micronutrient fertilizers are hardly used and thus need to introduce $\mathrm{Zn}$-based fertilizers.

\section{Straw and Grain yield}

Straw and grain yield ranged from 2.4 to $8.7 \mathrm{t} / \mathrm{ha}$ and 3.3 to $8.2 \mathrm{t} /$ ha respectively. Mean values for straw and grain yield are shown in Table 2 .

Table-2: Mean straw and grain yield

\begin{tabular}{|l|l|l|}
\hline Unit & Straw(t/ha) & Grain(t/ha) \\
\hline Mwea & $5.0^{\mathrm{ab}}$ & $5.8^{\mathrm{ab}}$ \\
\hline Thiba & $6.2^{\mathrm{a}}$ & $6.8^{\mathrm{a}}$ \\
\hline Wamumu & $5.1^{\mathrm{ab}}$ & $5.6^{\mathrm{ab}}$ \\
\hline Karaba & $4.4^{\mathrm{b}}$ & $5.0^{\mathrm{b}}$ \\
\hline Tebere & $5.4^{\mathrm{ab}}$ & $5.6^{\mathrm{ab}}$ \\
\hline Overall mean & 5.1 & 5.6 \\
\hline
\end{tabular}

Means followed by the same superscript letter in a column are not significant at $5 \%$ level

Yields decreased down the elevation with higher yields observed in Thiba unit and lowest in Karaba (Table 2). Grain yield was lower than potential yield of 10t/ha according to Ministry of Agriculture [6].

\section{Straw and grain nutrient content}

Average total straw and grain nutrient contents are shown in Tables 3 and 4 respectively with deficiency level according to Dobermann and Fairhurst [14].

Table-3: Mean straw total nutrient concentration

\begin{tabular}{|l|l|l|l|l|l|l|}
\hline Total nutrient (\%) & Deficiency level & Mwea & Thiba & Wamumu & Karaba & Tebere \\
\hline $\mathrm{Zn}$ & 0.0030 & $0.0059^{\mathrm{a}}$ & $0.0042^{\mathrm{b}}$ & $0.0052^{\mathrm{ab}}$ & $0.0044^{\mathrm{ab}}$ & $0.0045^{\mathrm{ab}}$ \\
\hline $\mathrm{Cu}$ & 0.0003 & $0.0024^{\mathrm{a}}$ & $0.0022^{\mathrm{a}}$ & $0.0026^{\mathrm{a}}$ & $0.0019^{\mathrm{b}}$ & $0.0012^{\mathrm{b}}$ \\
\hline $\mathrm{Fe}$ & 0.0350 & $0.1045^{\mathrm{a}}$ & $0.0581^{\mathrm{a}}$ & $0.1509^{\mathrm{a}}$ & $0.0967^{\mathrm{a}}$ & $0.1303^{\mathrm{a}}$ \\
\hline $\mathrm{Mn}$ & 0.0450 & $0.0590^{\mathrm{b}}$ & $0.0926^{\mathrm{ab}}$ & $0.0869^{\mathrm{ab}}$ & $0.0802^{\mathrm{b}}$ & $0.0822^{\mathrm{a}}$ \\
\hline $\mathrm{P}_{2} \mathrm{O}_{5}$ & 0.1000 & $0.3303^{\mathrm{a}}$ & $0.2448^{\mathrm{a}}$ & $0.3092^{\mathrm{a}}$ & $0.2139^{\mathrm{a}}$ & $0.2416^{\mathrm{a}}$ \\
\hline $\mathrm{S}$ & 0.0750 & $0.0696^{\mathrm{b}}$ & $0.0864^{\mathrm{b}}$ & $0.0857^{\mathrm{b}}$ & $0.0840^{\mathrm{b}}$ & $0.0896^{\mathrm{a}}$ \\
\hline $\mathrm{K}$ & 1.4000 & $0.6619^{\mathrm{c}}$ & $0.6858^{\mathrm{c}}$ & $1.4574^{\mathrm{ab}}$ & $1.5985^{\mathrm{bc}}$ & $1.6725^{\mathrm{a}}$ \\
\hline $\mathrm{Mg}$ & 0.2000 & $0.2687^{\mathrm{ab}}$ & $0.2280^{\mathrm{b}}$ & $0.2729^{\mathrm{ab}}$ & $0.2850^{\mathrm{b}}$ & $0.3028^{\mathrm{a}}$ \\
\hline $\mathrm{Ca}$ & 0.3000 & $0.2793^{\mathrm{a}}$ & $0.2511^{\mathrm{a}}$ & $0.3266^{\mathrm{a}}$ & $0.3828^{\mathrm{a}}$ & $0.3244^{\mathrm{a}}$ \\
\hline
\end{tabular}

Means followed by the same letter in a row are not significantly different at $5 \%$ level

For nutrients to accumulate in straw, they are taken from soil through transpiration stream [20]. This depends on nutrient availability, soil condition and plant factors. Most nutrients exceeded deficiency level in straw except for total $\mathrm{S}$ in Mwea and total $\mathrm{K}$ and $\mathrm{Ca}$ in Mwea and Thiba (Table 3). Positive associations between soil and straw nutrient accumulations were observed except $\mathrm{Zn}$ which showed high straw accumulation despite being deficient in soil.
Accumulation in edible parts occurs through redistribution of accumulated nutrients or continuous soil uptake. Phloem transport from old to new leaves is involved and depends on element mobility [20]. Grain total $\mathrm{Cu}, \mathrm{Mn}, \mathrm{P}_{2} \mathrm{O}_{5}$ and $\mathrm{Zn}$ exceeded deficiency level while total $\mathrm{Ca}, \mathrm{Fe}, \mathrm{K}, \mathrm{Mg}$ and $\mathrm{S}$ were deficient (Table 4). 
Table-4: Mean grain total nutrient concentration

\begin{tabular}{|l|l|l|l|l|l|l|}
\hline Total nutrient (\%) & Deficiency level* & Mwea & Thiba & Wamumu & Karaba & Tebere \\
\hline $\mathrm{Zn}$ & 0.0020 & $0.0050^{\mathrm{a}}$ & $0.0044^{\mathrm{b}}$ & $0.0045^{\mathrm{b}}$ & $0.0046^{\mathrm{ab}}$ & $0.0044^{\mathrm{b}}$ \\
\hline $\mathrm{Cu}$ & 0.0010 & $0.0017^{\mathrm{ab}}$ & $0.0016^{\mathrm{ab}}$ & $0.0019^{\mathrm{a}}$ & $0.0013^{\mathrm{b}}$ & $0.0018^{\mathrm{ab}}$ \\
\hline $\mathrm{Fe}$ & 0.0250 & $0.0085^{\mathrm{a}}$ & $0.0086^{\mathrm{a}}$ & $0.0097^{\mathrm{a}}$ & $0.0134^{\mathrm{a}}$ & $0.0119^{\mathrm{a}}$ \\
\hline $\mathrm{Mn}$ & 0.0050 & $0.0083^{\mathrm{b}}$ & $0.0112^{\mathrm{a}}$ & $0.0092^{\mathrm{ab}}$ & $0.0080^{\mathrm{b}}$ & $0.0086^{\mathrm{ab}}$ \\
\hline $\mathrm{P}_{2} \mathrm{O}_{5}$ & 0.2000 & $0.6915^{\mathrm{a}}$ & $0.6133^{\mathrm{b}}$ & $0.6475^{\mathrm{b}}$ & $0.6347^{\mathrm{b}}$ & $0.6454^{\mathrm{b}}$ \\
\hline $\mathrm{S}$ & 0.1000 & $0.0751^{\mathrm{b}}$ & $0.0731^{\mathrm{b}}$ & $0.0734^{\mathrm{b}}$ & $0.0729^{\mathrm{b}}$ & $0.0790^{\mathrm{a}}$ \\
\hline $\mathrm{K}$ & 0.2900 & $0.1844^{\mathrm{ab}}$ & $0.1705^{\mathrm{c}}$ & $0.1901^{\mathrm{ab}}$ & $0.1755^{\mathrm{bc}}$ & $0.1977^{\mathrm{a}}$ \\
\hline $\mathrm{Mg}$ & 0.1500 & $0.1285^{\mathrm{a}}$ & $0.1182^{\mathrm{b}}$ & $0.1219^{\mathrm{b}}$ & $0.1192^{\mathrm{b}}$ & $0.1220^{\mathrm{b}}$ \\
\hline $\mathrm{Ca}$ & 0.0500 & $0.0393^{\mathrm{a}}$ & $0.0385^{\mathrm{a}}$ & $0.0395^{\mathrm{a}}$ & $0.0369^{\mathrm{a}}$ & $0.0342^{\mathrm{a}}$ \\
\hline
\end{tabular}

*Dobermann and Fairhurst [14]

Means followed by the same letter in a row are not significantly different at $5 \%$ level

Remobilization moves nutrients to developing seeds provided senescence and seed import are synchronized to provide source-sink relationships [21].

High grain phosphorus could have come from continuous soil uptake and remobilization. Sulphur is less mobile and its deficiency reduces grain yield and quality by $10-40 \%$ without visible symptoms [22]. Pot experiments revealed $\mathrm{S}$ deficiency indicated by $\mathrm{N}: \mathrm{S}$ ratios of 16 and 25 significantly affect grain quality [23]. Enhancing N nutrition to reduce N: S ratio could help improve $S$ accumulation in grain. Increased $S$ application after anthesis enhanced its accumulation in grain [23], thus need to properly time $\mathrm{S}$ application.

Low grain $\mathrm{Mg}(<0.15 \%)$ could be attributed to binding by phytic acid known chelate metal cations [24]. Unbalanced crop fertilization with N:P:K reduces $\mathrm{Mg}$ in seeds [25], thus balanced crop nutrition should be considered. Grain total K was below deficiency level because of cation imbalance that negated its uptake and accumulation. Since $\mathrm{K}, \mathrm{Mg}$ and $\mathrm{P}$ accumulate in the aleurone layer [26], it is likely that phytic acid complexes them.

Grain $\mathrm{Zn}$ was high because it is loosely bound and localized in aleurone layer and inner endosperm thus not masked by phytic acid. Similarly, $\mathrm{Cu}$ passes the aleurone layer without being captured by phytic acid [27]. Prolonged submerged conditions, low soil $\mathrm{Zn}$ and $\mathrm{N}$ negate Fe uptake and accumulation.

According to Shi et al. [28], N nutrition showed positive effect on $\mathrm{Fe}$ and $\mathrm{Zn}$ translocation. Additional and timely $\mathrm{N}$ supply in wheat enhanced grain $\mathrm{Fe}$ and $\mathrm{Zn}$ [29] because of increased protein and sink strength. Therefore timely and appropriate $\mathrm{N}$ nutrition should be considered to enhance grain $\mathrm{Fe}$ and Zn. In Wang et al., [30], Zn fertilization with alternative wet and drying decreased phytic acid and increased yield. Further research into this aspect is necessary to elucidate this on Mwea soils and Kenyan rice varieties.

\section{Conclusions}

Spatial variability in soil properties plays a role in modeling and natural resource management. Soil results indicated high nutrient supplying power with deficiencies in $\mathrm{N}, \mathrm{Zn}$ and $\mathrm{K}$ grain nutrient status. Reasonable grain yields were obtained but of poor quality.

\section{RECOMMENDATIONS}

An improvement in limiting nutrients like $\mathrm{N}$, $\mathrm{Zn}$ and $\mathrm{K}$ at appropriate time could help avert the negative effects reflected in grain yield and quality. Appropriate field practices like mid-season drainage could also help in nutrient availability and uptake.

\section{ACKNOWLEDGEMENT}

We are indebted to Japan Science and Technology (JST) and Japan International Cooperation Agency (JICA) for funding through SATREPS. Many thanks to rice farmers in Mwea, entire Kenya Agricultural and Livestock Research Organization (KALRO) and Mwea Irrigation and Agricultural Development Centre (MIAD).

\section{REFERENCES}

1. Shapouri S., Rosen S., Peters M., Baquedano F. \& Allen S. (2010). Food security assessment. 201020, DIANE Publishing.

2. International Fertilizer Development Center (IFDC). (2006). Africa Fertilizer Summit Proceedings, Abuja, Nigeria.

3. Giller, K. E., Tittonell, P., Rufino, M. C., Van Wijk, M. T., Zingore, S., Mapfumo, P., ... \& Rowe, E. C. (2011). Communicating complexity: integrated assessment of trade-offs concerning soil fertility management within African farming systems to support innovation and development. Agricultural systems, 104(2), 191203.

4. Seck, P. A., Tollens, E., Wopereis, M. C., Diagne, A., \& Bamba, I. (2010). Rising trends and variability of rice prices: Threats and opportunities 
for sub-Saharan Africa. Food Policy, 35(5), 403411.

5. Atera E.A., Onyango J.C., Azuma T. Asanuma S., Itoh K. (2011). Field evaluation of selected NERICA rice cultivars in western Kenya. African Journal of Agricultural Research. 6(1):60-66

6. Ministry of Agriculture. (2008). National Rice Development Strategy (2008 - 2018). Agricultural Information Resource Centre, Nairobi, Kenya.

7. Atera, E. A., Onyancha, F. N., \& Majiwa, E. B. (2018). Production and marketing of rice in Kenya: Challenges and opportunities. Journal of Development and Agricultural Economics, 10(3), 64-70.

8. Marschner, P. (ed.). (2012). Marschner's mineral nutrition of higher plants, $3^{\text {rd }} \mathrm{Ed}$. Academic Press, San Diego, CA, USA

9. Sharma, A., Patni, B., Shankhdhar, D., \& Shankhdhar, S. C. (2013). Zinc-an indispensable micronutrient. Physiology and Molecular Biology of Plants, 19(1), 11-20.

10. Shoji, K., Kawamura, T., Horio, H., Nakayama, K., \& Kobayashi, N. (2005). Variability of microelevation, yield, and protein content within a transplanted paddy field. Precision Agriculture, 6(1), 73-86.

11. Ning H.F., Liu Z.H., Wang Q.S., Lin Z.M., Chen S.J., Li G.H., Wang S.H. \& Ding Y.F. (2009). Effect of nitrogen application on grain phytic acid and protein concentrations in japonica rice and its variations with genotypes. Journal of Cereal Science. 50, 49-55.

12. Kihoro, J., Bosco, N. J., Murage, H., Ateka, E., \& Makihara, D. (2013). Investigating the impact of rice blast disease on the livelihood of the local farmers in greater Mwea region of Kenya. SpringerPlus, 2(1), 308.

13. Koyama T. \& Sutoh M. (1987) Simultaneous multi-element determination of soils, plant and animal samples by inductively coupled plasma emission spectrometry. Japanese Journal of Soil Science and Plant Nutrition. 58,578-585 (In Japanese)

14. Dobermann A. \& Fairhurst T. (2000). Rice: Nutrient disorders \& nutrient management Manila, Philippines: Potash \& Phosphate Institute and International Rice Research Institute. pp 192.

15. Brady, N. C., \& Weil, R. R. (2014). The nature and properties of soil (14th New Int. Ed.).

16. Kondo M., Toshinari O.T.A. \& Wanjogu R. (2001). Physical and chemical properties of Vertisols and soil nutrient management for intensive rice cultivation in the Mwea area in Kenya. Japanese Journal of Tropical Agriculture. 45, 126-132.

17. Dobermann, A., Cassman, K. G., Mamaril, C. P., \& Sheehy, J. E. (1998). Management of phosphorus, potassium, and sulfur in intensive, irrigated lowland rice. Field Crops Research, 56(1-2), 113138.
18. Onderi J.N. (2016). Suitability Assessment of Effluents from Mwea Irrigation Scheme for reuse in Irrigation for Rice Production, Kirinyaga County, Kenya. Unpublished MSc Thesis, Kenyatta University.

19. Muriithi N.T., Karoki K.B. \& Gachanja A.N. (2012). Chemical and Mineral Analyses of Mwea clays. International Journal of Physical Sciences. 7, 5865-5869.

20. Sperotto, R. A. (2013). Zn/Fe remobilization from vegetative tissues to rice seeds: should I stay or should I go? Ask Zn/Fe supply! Frontiers in Plant Science, 4, 464.

21. Waters, B. M., \& Sankaran, R. P. (2011). Moving micronutrients from the soil to the seeds: genes and physiological processes from a biofortification perspective. Plant Science, 180(4), 562-574.

22. Khurana, N. E. E. N. A., Gupta, J. Y. O. T. I., \& Chatterjee, C. (1999). Sulphur deficiency influences metabolism and grain quality of rice. Indian Journal of Plant Physiology, 4(4), 277281.

23. Randall, P. J., Freney, J. R., \& Spencer, K. (2003). Diagnosing sulfur deficiency in rice by grain analysis. Nutrient Cycling in agroecosystems, 65(3), 211-219.

24. Raboy, V. (2009). Approaches and challenges to engineering seed phytate and total phosphorus. Plant Science, 177(4), 281-296.

25. Guo W., Nazim H., Liang Z. \& Yang D. (2016). Magnesium deficiency in plants: An urgent problem. The crop Journal. 4, 83-91.

26. Ogawa, M., Tanaka, K., \& Kasai, Z. (1979). Accumulation of phosphorus, magnesium and potassium in developing rice grains: followed by electron microprobe X-ray analysis focusing on the aleurone layer. Plant and Cell Physiology, 20(1), 19-27.

27. Iwai, T., Takahashi, M., Oda, K., Terada, Y., \& Yoshida, K. T. (2012). Dynamic changes in the distribution of minerals in relation to phytic acid accumulation during rice seed development. Plant Physiology, 160(4), 2007-2014.

28. Shi, R., Weber, G., Köster, J., Reza-Hajirezaei, M., Zou, C., Zhang, F., \& von Wirén, N. (2012). Senescence-induced iron mobilization in source leaves of barley (Hordeum vulgare) plants. New Phytologist, 195(2), 372-383.

29. Slamet-Loedin, I. H., Johnson-Beebout, S. E., Impa, S., \& Tsakirpaloglou, N. (2015). Enriching rice with $\mathrm{Zn}$ and $\mathrm{Fe}$ while minimizing $\mathrm{Cd}$ risk. Frontiers in plant science, 6, 121.

30. Wang Y.Y., Wei Y.Y., Dong L.X., Lu L.L., Feng Y., Zhang J., Pan F.S. and Yang X.E. (2014). Improved yield and $\mathrm{Zn}$ accumulation for rice grain by $\mathrm{Zn}$ fertilization and optimized water management. Journal of Zhejiang UniversityScience B (Biomedicine \& Biotechnology), 15(4): 365-374. 